\title{
Dual Language Books
}

Picture books are a great way to introduce new languages to children whose first language is English, or to introduce English to children who speak other languages at home. Books that present different languages alongside English also show respect for various cultural groups living in Canada and provide insight into groups separate from one's own.

Many young children aren't aware how language works - that different people can use different words to represent the world and their experiences in it. Michif, for example, emerged at the time of the fur trade and descends from the Métis people of Canada; it includes Cree verbs and French nouns. Julie Flett's Owls See Clearly at Night: A Michif Alphabet, connects Michif and English words with images from Métis culture, and we discuss this book in Chapter 11 along with other Canadian classics.

In this chapter we present some of our favourite dual language Canadian picture books published between 2017 and 2019, while other dual language books appear elsewhere in this guide. We maintained this group of books in order to assist readers who are specifically seeking material that demonstrates languages other than English. Many titles in this section focus on Indigenous languages while others explore languages with origins in different countries. Some of the books are fully translated, while others include single non-English words in a larger English story context. Of the thirteen books listed, nine have Indigenous languages included, and four involve languages from various other cultures - an interesting picture of the newer books available in this thematic category. Enjoy the linguistic diversity in these titles; they will undoubtedly provide children with new tools to understand the world!

Where not otherwise indicated, the name of the author(s) appears first under each title, and the illustrator last.

(C) BEVERLEY BRENNA, RICHARD DIONNE AND THERESA TAVARES, 2021 
Una Huna?: What is This?

Susan Aglukark,

Amanda Sandland

and Danny Christopher

A little girl from an isolated northern camp learns to use knives, forks, and spoons obtained during trading but soon wonders if they are a harbinger of change. Many Inuktitut words appear within the English text as well as in a glossary. Susan Aglukark is Canada's first Inuk artist to have won a Juno Award and is also an officer of the Order of Canada. For

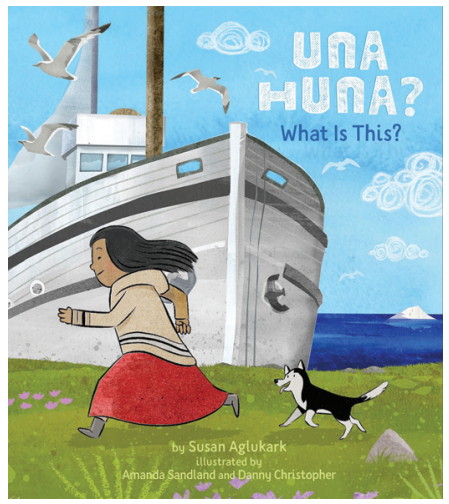
ages $5^{-8}$.

Me, Me, Me

Annika Dunklee

and Lori Joy Smith

Three best friends decide to form an all-girl singing group for the talent show, and conflict emerges. In addition to English, the book includes some conversations in Swedish and French, with English translations, in addition to Annie's made-up words. Children and families can be encouraged to create their own multi-language stories in response. Lori Joy Smith's whimsical, bright digital illustrations are further enhanced by speech-bubble dialogue. For ages $5^{-8}$.

\section{A Day with Yayah \\ Nicola I. Campbell \\ and Julie Flett}

Here a First Nations family gathers edible plants and mushrooms as Yayah, the grandmother, passes down her knowledge of the natural world. Language from the Nle?kepmx Nation (the Thompson River Salish people) is embedded in the text, and a glossary of Nłe?kepmxcín words is available at the end of the book. Nicola I. Campbell is Interior Salish and Métis and sets this book in her own territory, the Nicola Valley. Julie Flett is a Cree-Métis artist whose distinctive illustrations shine here. For ages $5^{-10+}$. 


\section{kimotinâniwiw itwêwina/Stolen Words}

Melanie Florence

and Gabrielle Grimard

This dual language edition, in Plains Cree and English, follows an original 2017 edition in English. It presents a poignant story of the relationship between a little girl and her grandfather, whose language was stolen from him when he was a boy at residential school. His granddaughter sets out to help him find his language again. Gabrielle Grimard's mixed-media illustrations, using watercolours, gouache and oil, as well as wooden pencil, are captivating. For ages $6-9+$.

\section{Kisimi Taimaippaktut}

Angirrarijarani/Only in My Hometown

Angnakuluk Friesen, Jean Kusugak (translator)

and Ippiksaut Friesen

Childhood memories in free verse celebrate growing up in a small Arctic town through warm images of family and community. The text is written in both Inuktitut (using both syllabics and transliterated roman orthography), which is placed first on each page, and English. Ippiksaut Friesen's striking illustra-

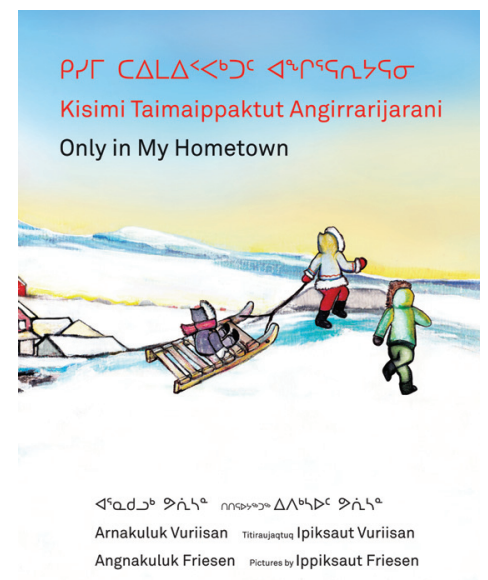
tions were painted with watercolour and acrylic "on elephant poo paper," and then composited digitally. The author/ illustrator team here are sisters. For ages $5^{-}$-adult.

Sus Yoo: The Bear's Medicine

Clayton Gauthier,

Danny Alexis

and Theresa Austin (translators)

This simple story tells about a mother bear caring for her baby in nature. The text is Dakelh and English. Clayton Gauthier is a multimedia artist who has apprenticed under the artist Peter George, a Wet'suwet'en master carver. For ages $5^{-9}$. 
Jujijk: Mi'kmaw Insects

Gerald Gloade

This illustrated guide to bugs and insects in Atlantic Canada showcases the verb-based Mi'kmaw language with English definitions and a pronunciation guide. Gerald Gloade is an artist from Millbrook First Nation. Jujijk is a joint project of the Tripartite Forum Culture \& Heritage and Education working committees. The vibrant mixedmedia illustrations combine hand-drawn elements and photographs. For ages 4-9+.

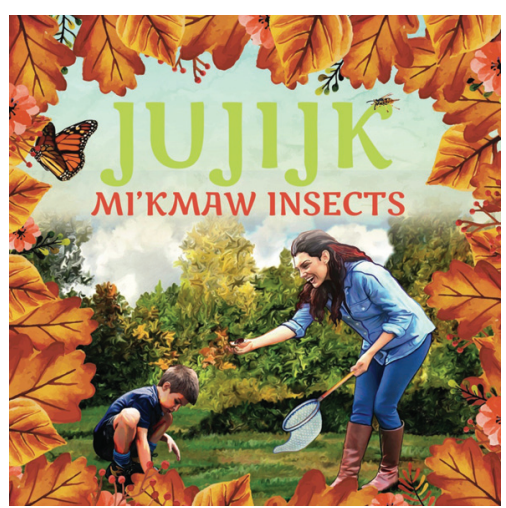

Awâsis and the World-Famous Bannock Dallas Hunt and Amanda Strong

A little girl loses her Kôhkum's bannock but she gets new ingredients from forest animals. Cree words are used in the context of the story and a list, with translations, appears at the back of the book along with the bannock recipe. Dallas Hunt is a member of Wapisewsipi (Swan

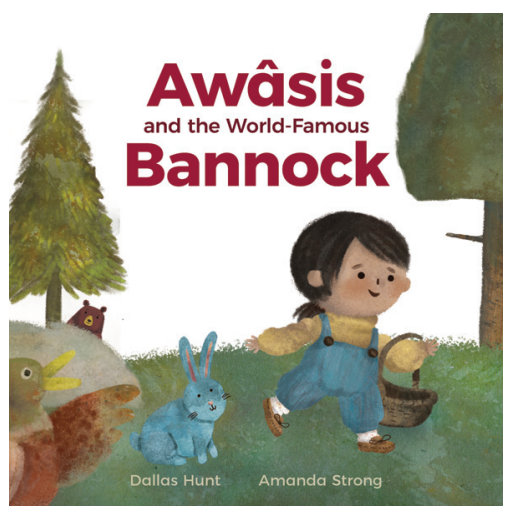
River First Nation) and Amanda Strong is a Michif filmmaker whose work here includes textures similar to cut-paper collage. This book connects especially well to various response activities, including oral retelling and dramatisation. For ages $4-8$.

\section{Meennunyakaa: Blueberry Patch}

Jennifer Leason (co-author and illustrator)

and Norman Chartrand (co-author and translator)

Norman Chartrand, an elder from Manitoba, shares childhood memories of blueberry picking. Both Chartrand and Jennifer Leason are Salteaux-MétisAnishinaabek people and the text appears in English and Anishinaabemowin. A recipe for bannock and suggested activities for readers are included at the end of the book. For ages 4-8. 
Bear for Breakfast/Makwa

kidji kijebà wìsiniyàn

Robert Munsch

and Jay Odjick

Donovan wants to catch a bear for breakfast just like his grandfather used to eat, but the bear has other plans in mind. The engaging comic-like digital illustrations are provided by the respected artist Jay Odjick, a member of the Kitigan Zibi Anishinabeg Algonquin community. This book is available in a dual language edition translated into Ojibwa by Joan

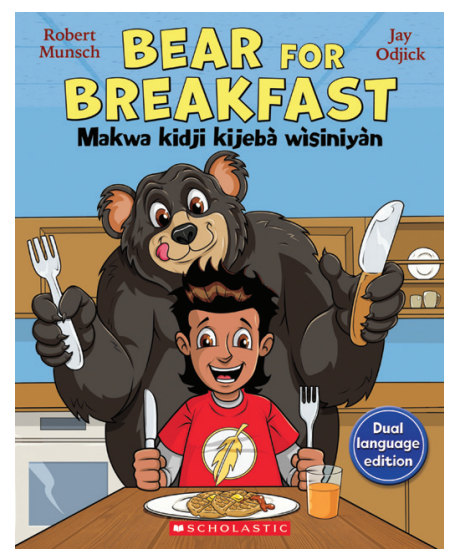
Commanda Tenasco. For ages 3-7.

\section{Nipêhon/I Wait}

Caitlin D. Nicholson

with Leona Morin-Neilson

This is a very easy-to-read story about a little girl, her mom, and her grandmother going on an outing to pick wild yarrow. A recipe for yarrow tea is included. The English text is translated into Cree by Leona Morin-Nielson (in both the standard Roman orthography and in syllabics), and Caitlin D. Nicholson's stunning acrylic paintings fill the book's oversize pages. For ages $2-7$.

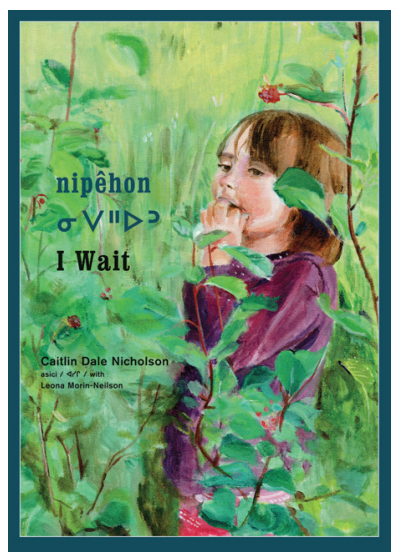

Light a Candle/Tumaini pasipo na Tumaini

Godfrey Nkongolo,

Eric Walters

\section{and Eva Campbell}

Written in both English and Swahili, this title follows a young boy as he climbs Mount Kilimanjaro against his father's wishes. Once there, he fulfills a political leader's request to light a candle and unify two territories. Ngama's fictional narrative is based on a true story. Eva Campbell's expansive oil paint and pastel illustrations reflect

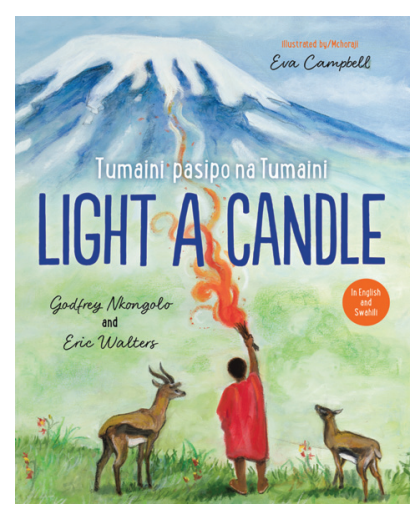
emotional depths. For ages $5^{-9}$. 


\section{Lucky Me \\ Lora Rozler \\ and Jan Dolby}

A little girl bursting with thankfulness for the many good things in her life shows readers how to say thank you in a variety of different languages besides English: Albanian, Arabic, Armenian, Cantonese, Cree, Dutch, Finnish, French, German, Greek, Hebrew, Hindi, Hungarian, Italian, Japanese, Korean, Mandarin, Persian, Polish, Portuguese, Punjabi, Romanian, Russian, Somali, Spanish, Swahili, Tagalog, Tamil, Turkish, Vietnamese, and Urdu. Jan Dolby's luminous, heartwarming illustrations are created with acrylic paint, watercolour, graphite and marker mixed with Adobe Photoshop and Illustrator techniques. For ages $3-8$.

\section{Ojiichan's Gift \\ Chieri Uegaki \\ and Genevieve Simms}

Ojiichan's Gift is about a little girl who helps her grandfather tend to his garden each time she visits Japan. When Ojiichan grows old and must move away, Mayumi creates a tiny stone garden in a bento box for him to keep. The story was inspired in part by Chieri Uegaki's late father, a traditional Japanese landscaper and gardener. The six Japanese words included in the story are defined on the copyright page, and offer a simple pattern for children to embed various languages in their own writing. Genevieve Simms' luminous watercolours create a moving representation of the bond between grandfather and granddaughter. For ages 4-8.

\section{Bibliography}

*In the spirit of the recommendations of the Truth and Reconciliation Commission, an asterisk appears beside works created by Indigenous writers or artists.

*Aglukark, Susan (illustrated by Amanda Sandland \& Danny Christopher) (2018). Una Huna? What is This? Iqaluit, NU: Inhabit Media.

*Campbell, Nicola I. (illustrated by Julie Flett) (2017). A Day with Yayah. Vancouver, BC: Tradewind Books. 
*Chartrand, Norman \& Leason, Jennifer (illustrated by Jennifer Leason; translated by Norman Chartrand) (2019). Meennunyakaa: Blueberry Patch. Penticton, BC: Theytus Books.

Dunklee, Annika (illustrated by Lori Joy Smith) (2017). Me, Me, Me. Toronto, ON: Kids Can Press.

*Florence, Melanie (illustrated by Gabrielle Grimard) (2019). kimotinâniwiw itwêwina / Stolen Words. Toronto, ON: Second Story Press.

*Friesen, Angnakuluk (illustrated by Ippiksaut Friesen; translated by Jean Kusugak) (2017). Kisimi taimaippaktut angirrarijarani/only in my hometown. Toronto, ON: Groundwood Books/House of Anansi Press.

*Gauthier, Clayton (translated by Danny Alexis and Theresa Austin) (2019). Sus Yoo: The Bear's Medicine. Penticton, BC: Theytus Books.

*Gloade, Gerald (2019). Jujijk: Mi'kmaw Insects. Halifax, NS: Nimbus Publishing.

*Hunt, Dallas (illustrated by Amanda Strong) (2017). Awâsis and the World-Famous Bannock. Winnipeg, MB: Highwater Press.

*Munsch, Robert (illustrated by Jay Odjick) (2019). Bear for Breakfast = Makwa kidji kijebà wisiniyàn. Toronto, ON: Scholastic Canada.

*Nicholson, Caitlin. D. (with Leona Morin-Neilson) (2017). Nipêhon = I Wait. Toronto, ON: Groundwood/House of Anansi Press.

Nkongolo, Godfrey \& Walters, Eric (illustrated by Eva Campbell) (2019). Tumaini pasipo na Tumaini: Light a Candle. Victoria, BC: Orca Book Publishers.

Rozler, Lora (illustrated by Jan Dolby) (2018). Lucky Me. Markham, ON: Fitzhenry \& Whiteside.

Uegaki, Chieri (illustrated by Genevieve Simms) (2019). Ojiichan's Gift. Toronto, ON: Kids Can Press. 